This article was downloaded by: [b-on: Biblioteca do conhecimento online UL]

On: 19 December 2013, At: 08:02

Publisher: Taylor \& Francis

Informa Ltd Registered in England and Wales Registered Number: 1072954 Registered office: Mortimer House, 37-41 Mortimer Street, London W1T 3J H, UK

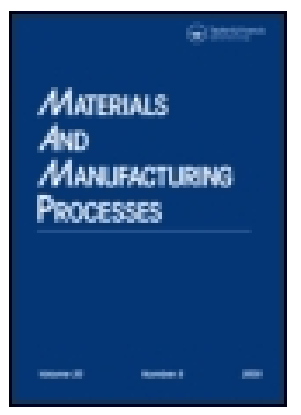

\title{
Materials and Manufacturing Processes
}

Publication details, including instructions for authors and subscription information: http:// www. tandfonline.com/loi/Immp20

\section{Fibulae from an Iron Age Site in Portugal}

\author{
A. A. Melo ${ }^{a}$, E. Figueiredo ${ }^{b c}$, M. F. Araújo ${ }^{b} \& J$. C. Senna-Martinez ${ }^{d}$ \\ a Museu Nacional de Arqueologia, Mosteiro dos J erónimos, Praça do Império, Lisboa, \\ Portugal \\ ${ }^{\mathrm{b}}$ Instituto Tecnológico e Nuclear (ITN), Sacavém, Portugal \\ c Departamento de Conservação e Restauro, Faculdade de Ciências e Tecnologia da \\ Universidade Nova de Lisboa, Monte de Caparica, Portugal \\ ${ }^{d}$ Centro de Arqueologia (Uniarq), Faculdade de Letras da Universidade de Lisboa, Lisboa, \\ Portugal \\ Published online: 04 Aug 2009.
}

To cite this article: A. A. Melo, E. Figueiredo , M. F. Araújo \& J. C. Senna-Martinez (2009) Fibulae from an Iron Age Site in Portugal, Materials and Manufacturing Processes, 24:9, 955-959, DOI: 10.1080/10426910902979835

To link to this article: http:// dx. doi.org/ 10.1080/10426910902979835

\section{PLEASE SCROLL DOWN FOR ARTICLE}

Taylor \& Francis makes every effort to ensure the accuracy of all the information (the "Content") contained in the publications on our platform. However, Taylor \& Francis, our agents, and our licensors make no representations or warranties whatsoever as to the accuracy, completeness, or suitability for any purpose of the Content. Any opinions and views expressed in this publication are the opinions and views of the authors, and are not the views of or endorsed by Taylor \& Francis. The accuracy of the Content should not be relied upon and should be independently verified with primary sources of information. Taylor and Francis shall not be liable for any losses, actions, claims, proceedings, demands, costs, expenses, damages, and other liabilities whatsoever or howsoever caused arising directly or indirectly in connection with, in relation to or arising out of the use of the Content.

This article may be used for research, teaching, and private study purposes. Any substantial or systematic reproduction, redistribution, reselling, loan, sub-licensing, systematic supply, or distribution in any form to anyone is expressly forbidden. Terms \& Conditions of access and use can be found at http:// www.tandfonline.com/page/terms-and-conditions 


\title{
Fibulae from an Iron Age Site in Portugal
}

\author{
A. A. Melo $^{1}$, E. Figueiredo ${ }^{2,3}$, M. F. Araújo ${ }^{2}$, and J. C. Senna-Martinez ${ }^{4}$ \\ ${ }^{1}$ Museu Nacional de Arqueologia, Mosteiro dos Jerónimos, Praça do Império, Lisboa, Portugal \\ ${ }^{2}$ Instituto Tecnológico e Nuclear (ITN), Sacavém, Portugal \\ ${ }^{3}$ Departamento de Conservação e Restauro, Faculdade de Ciências e Tecnologia da Universidade Nova de Lisboa, \\ Monte de Caparica, Portugal \\ ${ }^{4}$ Centro de Arqueologia (Uniarq), Faculdade de Letras da Universidade de Lisboa, Lisboa, Portugal
}

\begin{abstract}
Castro de Pragança is located in Estremadura province, on the Portuguese Western coast. Although most of the metal artifacts found in the site can be dated to Copper and Bronze Ages, an unusual set of nine fibulae was recovered. They can be dated to the period from the Iron Age until the Roman conquest. Nondestructive micro-EDXRF elemental analyses showed that five of the fibulae are made of bronze (Cu-Sn alloy), while four fibulae have a polymetallic character and are made both of bronze and iron. This fact indicates exceptionally important archaeological and technological issues.
\end{abstract}

Keywords Fibulae; Iron Age; Micro-EDXRF; Portugal.

\section{INTRODUCTION}

The site of Castro de Pragança (Cadaval, Estremadura) is located on a hilltop near Cadaval (Fig. 1), a village, about $55 \mathrm{~km}$ North of Lisbon, in the Portuguese province of Estremadura and was discovered by the end of the 19th century (1893). The place was known as a "castle" by the local population at the time of its discovery, and it was excavated by Dr. J. Leite de Vasconcelos, the first director of the Museu Nacional de Arqueologia (Lisbon, Portugal). During his archaeological fieldwork-he directed several campaigns until the beginning of the 20th century-he recovered an enormous amount of artifacts, including ceramics and one of the largest collections of metal artifacts and metal debris found in a Portuguese prehistoric settlement. Later, about 1930, Trindade surveyed this site and cut some test trenches. In 1988 and 1990more than fifty years later-new excavations were carried out by Gonçalves [1] who focused the fieldwork mainly in the identification of the fortification wall perimeter.

The Estremadura Copper Age is frequently characterized by the recurring theme of fortified settlements. Castro de Pragança is no exception, and several articles on this settlement, published in the past, focused mainly on this issue [1]. The site is often quoted as a typical example of Chalcolithic fortified settlement found in Western Portugal; however, it has in fact a much longer time span occupation which goes from the Copper Age through the Bronze and Iron Ages. Above all, Castro de Pragança provided one of the largest collections of prehistoric metal artifacts belonging to the Museu Nacional de Arqueologia: more than 500 artifacts, artifacts fragments, and metal remains,

Received October 11, 2008; Accepted December 23, 2008

Address correspondence to A. A. Melo, Museu Nacional de Arqueologia, Mosteiro dos Jerónimos, Praça do Império, Lisboa 1400206, Portugal; E-mail: mnarq.amelo@ipmuseus.pt including slag and metal debris. Among all these metal artifacts and remains, there is a group of nine fibulae, dated to the Iron Age, which represent a rather unusual finding for such a settlement in Portuguese Estremadura.

\section{Castro de praganÇA fibulae}

Tools and weapons are the majority of metal artifacts recovered from Castro de Pragança, although there is a significant group of artifacts that can be classified as adornments. The majority of the artifacts can be attributed to the Bronze Age, but there are two important groups that can be dated to the Copper and to the Iron Ages. Among the items belonging to the Iron Ages, there is a set of nine fibulae that is most unusual. According to typological classification, they can be dated to the period from the Iron Age through to the Roman Conquest. Prehistoric fibulae are prestige items, and for that reason they are usually recovered from burials. This is, however, not the case with the fibulae from Castro de Pragança.

None of the nine fibulae is complete. The recurrent absence of some of the fibula components-bow, head, and foot-made the typological classification of these artifacts more difficult. Because of this, the typological classification was carried out mainly on the base of one or two of the components, usually the bow and sometimes also the head. Part of this fibulae collection-six fibulae-has recently been classified and published [2].

The typology of the fibulae identifies them as objects of local production. The group of fibulae may be attributed to four main typological groups. These are Acebuchal, La Tène I, Trasmontano (La Tène I subtype), and La Tène III types.

\subsection{Acebuchal Type}

Castro de Pragança has two fibulae fragments (2005.10.26 and 2005.10.27) that can be classified as Acebuchal type (Fig. 2). One of the fibulae presents a bow composed of 


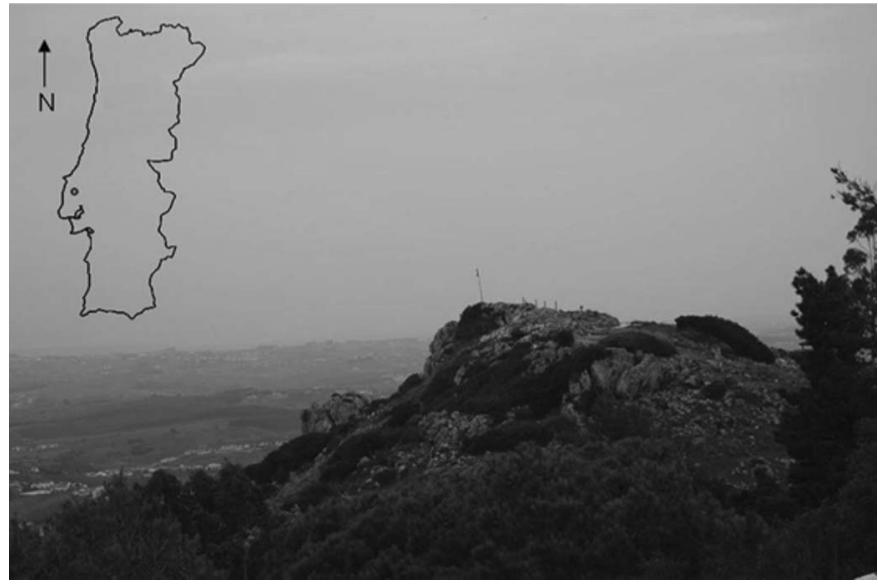

Figure 1.-Castro de Pragança (photograph by Ana Sousa) and its location in the Portuguese territory (top left).

two divided thin plates with decoration-longitudinal stria fillet - and part of the foot. A rivet fixes the bow and the foot. The second fibula fragment is very corroded and also presents a bow composed of two divided thin plates with the same kind of decoration: longitudinal stria fillet.

The spring is missing in both fragments, and in both cases the bow is composed of a divided thin plate. In the Iberian Peninsula, the Acebuchal type is very common during the 1st Iron Age. According to Ponte [2], this particular type was developed during the period between the 8th and the 7th century B.C., it presents western Mediterranean influences and may be related with other 1st Iron Age Iberian fibulae, such as the Alcores or Bencarrón types.

\subsection{La Tène I Type}

The fibula 2005.10.18 (Fig. 3) is one of the most complete brooches of this collection since it has the complete spring, part of the pin, and part of the bow. This particular type, a local production which Ponte [2] has connected with the La Tène I fibulae, was invented during the 1st Iron Age (in the 7th century B.C.) and fully developed and widespread during the 2nd Iron Age (through the 6th century B.C., and until the 3rd century B.C., when the Roman conquest begun).

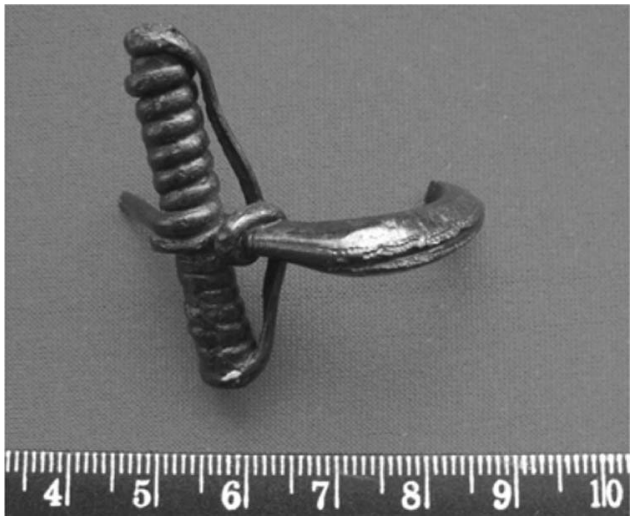

Figure 3.—La Tène I fibula 2005.10.18.

\subsection{Transmontano Type}

Among the wide group of La Tène I fibulae, there is a particular shape which is known as a local production of the Portuguese NE region (Fig. 4). This group was identified at the beginning of the 20th century [2], but recent research showed that it is rather common also in the Northern Iberian Peninsula, where it is namely associated with NW Iberia Iron Age Hill Fort culture (cultura castreja). This type of fibula was developed at the beginning of the 2nd Iron Age (5th century B.C.) and continued to be in circulation through the 1st century B.C., after the Roman Conquest. These fibulae are composed of two independent parts, i.e., the bow and the spring, and the bow has a typical vessel shape. In the Pragança collection there are five items recently classified as Trasmontano type fibulae [2]. All of them have vessel shaped bows, but they may be subdivided in two subtypes, according to the presence (2005.10.75, 2005.10.76, and 983.299.180) or absence (2005.10.79 and 2005.10.80) of a turned up foot, bent back towards the bow.

\subsection{La Tène III Type}

In the group, there is only one fibula classified as $L a$ Tène III (983.299.164) (Fig. 5). It shows a vessel shaped bow with decoration (incised longitudinal lines); the head consists of a tubular element in which part of the axle is inserted. This particular type was employed in the period from the 3rd century B.C. through to the 1 st century A.D. and was widespread throughout the Iberian Peninsula

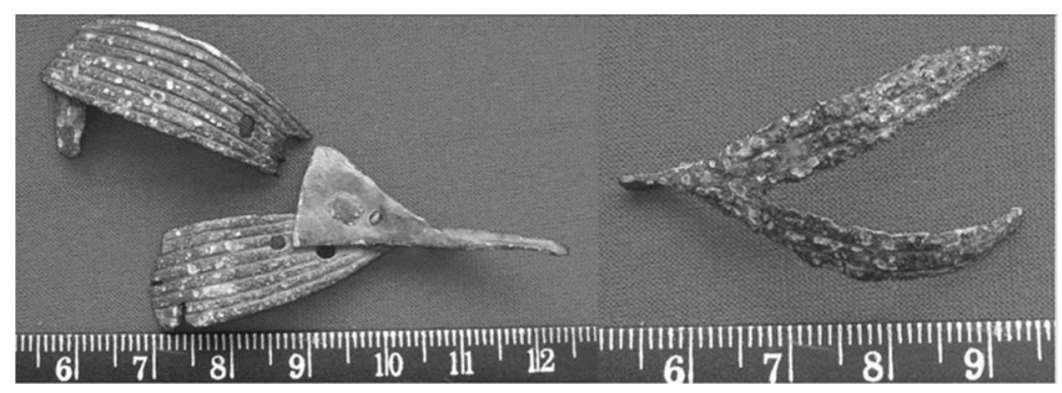

FIGURE 2.-Acebuchal type fibulae, 2005.10.26 (left) and 2005.10.27 (right). 


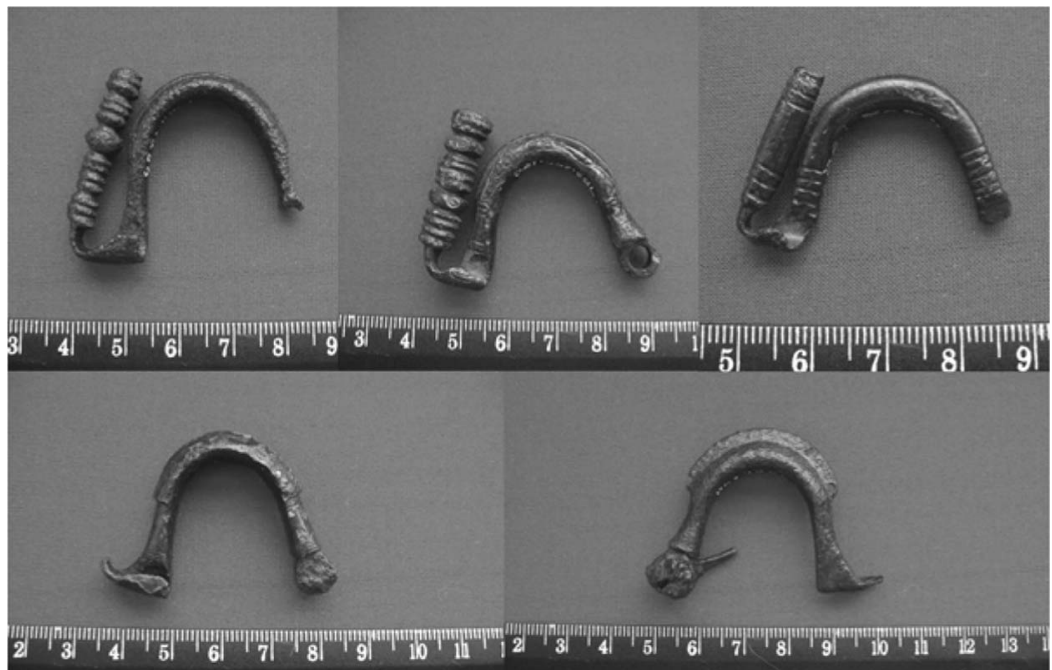

FigURE 4.-Transmontano type fibulae (from top left to bottom right): 2005.10.75; 983.299.180; 2005.10.76; 2005.10.80; 2005.10.79.

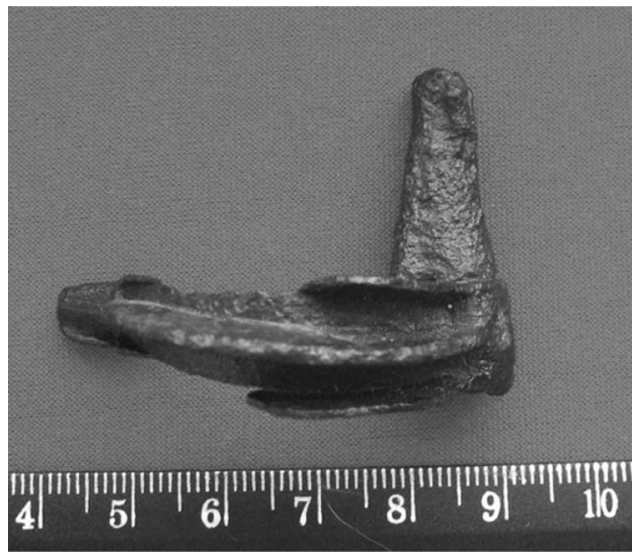

FIGURE 5.—La Tène III fibula 983.299.164.

mainly from the end of the 2nd Iron Age to the time of Augustus.

\section{NONDESTRUCTIVE MICRO-ENERGY-DISPERSIVE X-RAY FLUORESCENCE SPECTROMETRY (MICRO-EDXRF) SUPERFICIAL ANALYSES OF THE FIBULAE}

Most of the fibulae exhibit more than one metallic component. The Acebuchal 2005.10.26 fibula, which consists of rivets, a foot, a bow, as well as a metal sheet that unites two bow parts, and the La Tène III fibula 983.299.164, which consists of the bow and foot elements, the axle, and the tubular beam can be taken as good examples of composite objects.

All fibulae clearly present a corroded surface, except for one, the fibula 2005.10.18 (La Tène I), which shows a small area with metal exposed in the bow.

Micro-Energy-Dispersive X-Ray Fluorescence Spectrometry (micro-EDXRF) analyses were performed on the surfaces of all the different elements that compose the fibulae. Whenever possible, a minimum of three analyses were performed on each component. The metallic surface exposed in the fibula 2005.10.18 was also analyzed. The analyses were performed with an ArtTAX Pro spectrometer, with a low-power X-ray tube, a molybdenium anode, and a set of polycapillary lens that generate a microspot, lower than $100 \mu \mathrm{m}$ in diameter, of primary radiation [3]. The quantification analyses involved the WinAxil software, and details on quantification procedures have been recently described $[4,5]$.

The analyses showed that most of the components were made of a $\mathrm{Cu}-\mathrm{Sn}$ alloy, with variable low amounts of $\mathrm{As}$ and $\mathrm{Pb}$ (Fig. 6). The quantification of the analyses carried out on the metal exposed on the bow of the fibula 2005.10.18 determined a copper alloy with $10.3 \pm 2.3 \% \mathrm{Sn}$ and $2.3 \pm 0.2 \% \mathrm{~Pb}$.

Only the axles of the 2005.10.80 and 2005.10.79 Transmontano type, the 2005.10.18 La Tène I type, and the 983.299.164 La Tène III type fibulae were not made of bronze, but essentially of iron (Fig. 7).

\section{DISCUSSION}

The results of the micro-EDXRF analyses show that all fibulae were made of bronze, with variable small amounts

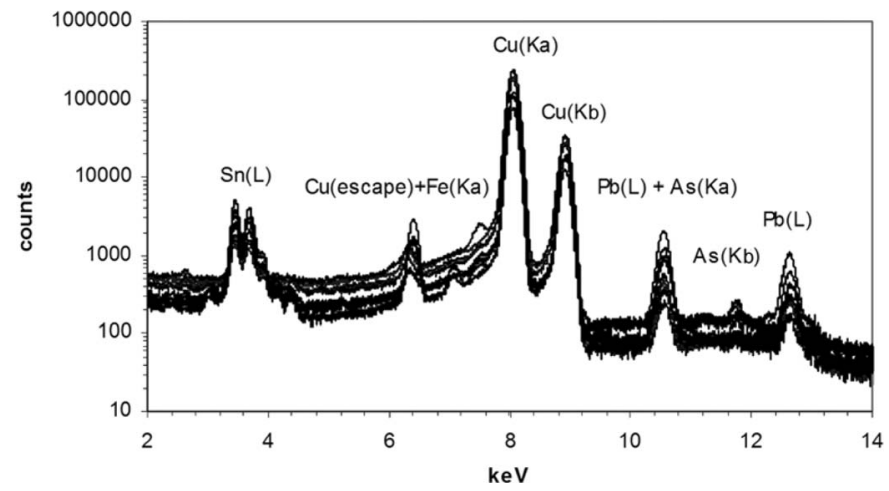

FIGURE 6.-Micro-EDXRF spectra of bronze components of the nine fibulae. 


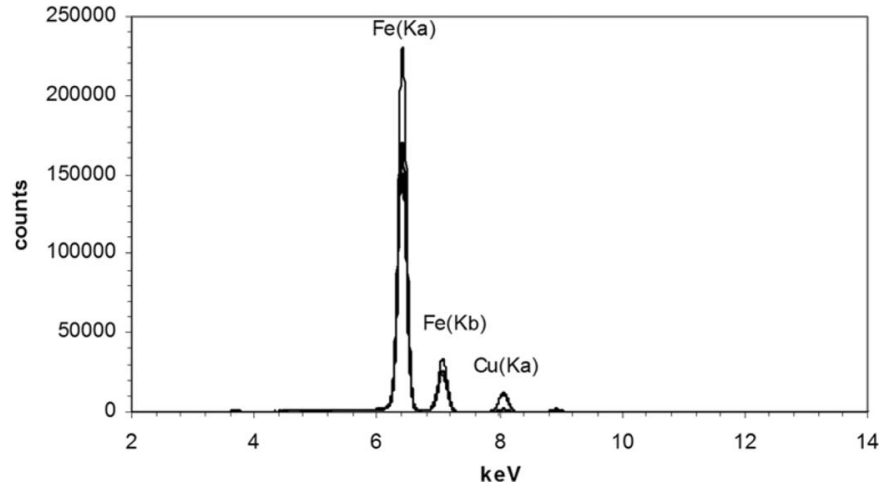

FIGURE 7.-Micro-EDXRF spectra of the iron axles of the 2005.10.18 $\mathrm{La}$ Tène I, 2005.10.79 and 2005.10.80 Transmontano, and 983.299.164 La Tène III type fibulae.

of As and/or $\mathrm{Pb}$, and that 4 fibulae (2005.10.80, 2005.10.79, 2005.10.18, and 983.299.164) have axles made of iron.

The use of bronze with variable $\mathrm{Pb}$ concentrations is consistent with Iron Age metallurgy and has been described in the manufacture of the 5th century B.C. Certosa brooches from Italy [6] and various non-Roman brooches from southeastern Alpine region [7]. The composition of the bronze in the La Tène I-type fibula 2005.10.18 ( 10\% Sn and $\sim 2 \% \mathrm{~Pb}$ ) is consistent with the variable composition of bronze artifacts in circulation during the Iron Age in the Iberian Peninsula. In earlier times, during the Late Bronze Age, bronze rarely contained $\mathrm{Pb}$ or it is just found at trace levels $(<2 \%)$, which can be associated to the raw materials. Only with the beginning of the Iron Age (i.e., with the Phoenician colonisation of the Iberian Peninsula at the beginning of the 1st millennium B.C.), Pb became a more frequent element in bronze alloys, with varying contents from $\sim 2 \%$ to much higher values $[8-10]$ ).

The last two types of fibulae, Transmontano and $\mathrm{La}$ Tène III (which have a time span from ca. 5th century $\mathrm{BC}$ to 1st century A.D.), were in use before and after the Roman Conquest. The use of bronze in the manufacture of these six fibulae is in agreement with a local indigenous manufacture, possibly in a pre-Romanized period, since brass was introduced in the Iberian Peninsula by the Romans, and among the Roman(ized) communities it was frequently used in the manufacture of brooches, from 60 B.C. onwards [7].

At the beginning of the 1st millennium B.C., iron was used in several places in the Mediterranean basin. The first iron objects in Iberian Peninsula appear in Late Bronze Age cultural contexts (many in contexts previous to the 9th century B.C., therefore Pre-Phoenician) and are frequently iron blades [11]. The polymetallic character-iron with gold or iron with bronze-is also a characteristic of these first iron artifacts. This fact suggests that this new metal was highly considered, explicitly in the case of the association of iron with gold, and had a special character.

In the case of the fibulae from Castro de Pragança, the use of iron for the manufacture of the less visible components of the objects, i.e., the axle, can indicate that iron was no longer considered a "precious" material as it seems to have been when it made its first appearance. The use of iron axels (at least since the 7th century B.C.) in substitution of previous bronze axles can be interpreted either as a new technological feature-as iron had more adequate mechanical properties - or for economic reasons, as a way of using less of the more precious bronze. Either way, in the social contexts, it seems to synchronize with a new social organization of the protohistoric communities, contributing to the specialization and division of the economic activities [12]. As a result, the fibulae seem to register the transition of an earlier period characterized by a traditional bronze domestic metallurgy to a forthcoming period of new materials and technologies.

\section{FinAL REMARKS}

The Iron Age fibulae from Castro de Pragança are probably locally produced, even though they reveal different foreign influences. Castro de Pragança as other sites dated to the recent Prehistory in the Portuguese Estremadura province received influences both from the Mediterranean and the Atlantic areas. In fact, the Portuguese Estremadura has a strategic location that, since very ancient times, provides a link between the Atlantic Western Europe, the Western Mediterranean, and the more interior Iberian regions with the Atlantic coast. The Phoenicians, who arrived in the early 1 st millennium to the Portuguese western coast, certainly exploited these contacts.

After the 5th century B.C. oriental influences decreased, and with them their cultural marks in the interior and western Portuguese regions. The Iron Age fibulae from Castro de Pragança seem to testify these cultural marks: the Acebuchal type fibulae mark the first stage (1st Iron Age) with the strongest oriental influences; the La Tène type (and Transmontano subtype) fibulae mark the later stage (2nd Iron Age), with the increasing influence of continental models that came through the interior regions of the Iberian Peninsula.

Micro-EDXRF are superficial analyses, nondestructive, and easy and quick to perform. Already this simple method demonstrated the regular use of bronze alloys with some $\mathrm{Pb}$ contents. This kind of alloy is in agreement with the metal used during the Iron Age in the Iberian Peninsula, when $\mathrm{Pb}$ becomes more common in the bronze than in the previous Late Bronze Age period.

Four fibulae, all of La Tène type, show a combination of bronze elements with an iron axle. The manufacture of the axle made of iron indicates that this metal was already fully assimilated in the indigenous settlements and was used with bronze either as a technological improvement or as an economical feature.

\section{ACKNOWLEDGMENTS}

This work has been carried out in the framework of the project POCTI/HAR/58678/2004, Metallurgy and Society in Central Portugal Late Bronze Age, financed by the Portuguese Science Foundation (FCT). E. F. acknowledges the FCT for the SFRH/BD/27358/2006 grant. 


\section{REFERENCES}

1. Gonçalves, J.L.M. Olelas e Pragança. Duas fortificações calcolíticas. O Arqueólogo Português 1990/1992, 8/10, 33-40.

2. Ponte, S. Corpus Signorum das Fíbulas Proto-Históricas e Romanas de Portugal; Caleidoscópio: Coimbra, Portugal, 2006; $572 \mathrm{pp}$.

3. Bronk, H.; Rohrs, S.; Bjeoumikhov, A.; Langhoff, N.; Schmalz, J.; Wedell, R.; Gorny, H.E.; Herold, A.; Waldschlager, U. ArtTAX-A new mobile spectrometer for Energy-Dispersive micro X-Ray fluorescence spectrometry on art and archaeological objects. Fresenius Journal of Analytical Chemistry 2001, 371 (3), 307-316.

4. Valério, P.; Araújo, M.F.; Canha, A. EDXRF and microEDXRF studies of late bronze age metallurgical productions from canedotes (Portugal). Nuclear Instruments and Methods in Physics Research B: Beam Interactions with Materials and Atoms 2007, 263, 477-482.

5. Figueiredo, E.; Valério, P.; Araújo, M.F.; Senna-Martinez, J.C. Micro-EDXRF surface analyses of a bronze spear head: Lead content in metal and corrosion layers. Nuclear Instruments and Methods in Physics Research A: Nuclear Instruments and Methods in Physics Research 2007, 580, 725-727.
6. Pinasco, M.R.; Stagno, E.; Ienco, M.G.; Piccardo, P.; Macellari, R.; Fiori, F. Manufacturing fifth century B.C. Certosa Brooches. JOM 2000, 52 (6), 13-15.

7. Istenic, J.; Smit, Z. The beginning of the use of brass in Europe with particular reference to the southern Alpine region. In Metal and Mines; La Niece, S.L; Hook, D.; Craddock, P., Eds.; Archetype: London, 2007.

8. Bettencourt, A. Aspectos da metalurgia do bronze durante a Protohistória do Entre Douro e Minho. Arqueologia 2001, 26, $13-37$.

9. Rovira, S.; Montero, I.; Ortega, J.; Ávila, J.J. Bronce y trabajo del bronce en el poblado orientalizante de "El Palomar" (Oliva de Mérida, Badajoz). Anejos de AEspA 2005, XXXV, 1231-1240.

10. Ruiz, I.; Ramos, P.; Rovira, S. Aspectos de la metalurgia orientalizante en Cancho Roano. In Cancho Roano IX; Los Materiales Arqueológicos II; Instituto de Historia: Madrid, Spain, 2003; 195-210.

11. Vilaça, R. Iron artefacts in contexts of the late bronze age in the Portuguese territory. Complutum 2006, 17, 81-101.

12. Ponte, S. In $3^{\circ}$ Simpósio sobre Mineração e Metalurgia Históricas no Sudoeste Europeu. Proceedings, Porto, Portugal, June 21-23, 2005; Sociedad Española para la Defensa del Património Geológico y Minero and IPPAR, 2006. 